University of Nebraska - Lincoln

DigitalCommons@University of Nebraska - Lincoln

Agronomy \& Horticulture -- Faculty Publications

Agronomy and Horticulture Department

2003

Nitrogen application influences the critical period for weed control in corn

Sean P. Evans

University of Nebraska-Lincoln

Stevan Z. Knezevic

University of Nebraska-Lincoln, sknezevic2@unl.edu

John L. Lindquist

University of Nebraska-Lincoln, jlindquist1@unl.edu

Charles A. Shapiro

University of Nebraska-Lincoln, cshapiro1@unl.edu

Erin E. Blankenship

University of Nebraska-Lincoln, erin.blankenship@unl.edu

Follow this and additional works at: https://digitalcommons.unl.edu/agronomyfacpub

Part of the Plant Sciences Commons

Evans, Sean P.; Knezevic, Stevan Z.; Lindquist, John L.; Shapiro, Charles A.; and Blankenship, Erin E., "Nitrogen application influences the critical period for weed control in corn" (2003). Agronomy \& Horticulture -- Faculty Publications. 410.

https://digitalcommons.unl.edu/agronomyfacpub/410

This Article is brought to you for free and open access by the Agronomy and Horticulture Department at DigitalCommons@University of Nebraska - Lincoln. It has been accepted for inclusion in Agronomy \& Horticulture -Faculty Publications by an authorized administrator of DigitalCommons@University of Nebraska - Lincoln. 


\section{Nitrogen application influences the critical period for weed control in corn}

Sean P. Evans

Former Graduate Student,

University of Nebraska, Lincoln, NE 68728.

Present address: University of Illinois, Macomb

Extension Center, Macomb, IL 61455

\section{Stevan Z. Knezevic}

Corresponding author. Haskell Agricultural

Laboratory, University of Nebraska, 57905866

Road, Concord, NE 68728; sknezevic2@unl.edu

John L. Lindquist

Department of Agronomy and Horticulture,

University of Nebraska, Lincoln, NE 68583

\section{Charles A. Shapiro}

Haskell Agricultural Laboratory, University of

Nebraska, 57905866 Road, Concord, NE 68728

\section{Erin E. Blankenship}

Department of Biometry, University of Nebraska, Lincoln, NE 68583

\begin{abstract}
The critical period for weed control (CPWC) is the period in the crop growth cycle during which weeds must be controlled to prevent unacceptable yield losses. Field studies were conducted in 1999 and 2000 in eastern Nebraska to evaluate the influence of nitrogen application on the CPWC in dryland corn in competition with a naturally occurring weed population. Nitrogen fertilizer was applied at rates equivalent to 0,60 , and $120 \mathrm{~kg} \mathrm{~N} \mathrm{ha}{ }^{-1}$. A quantitative series of treatments of both increasing duration of weed interference and length of weed-free period were imposed within each nitrogen main plot. The beginning and end of the CPWC based on an arbitrarily 5\% acceptable yield loss level were determined by fitting the logistic and Gompertz equations to relative yield data representing increasing duration of weed interference and weed-free period, respectively. Despite an inconsistent response of corn grain yield to applied nitrogen, there was a noticeable influence on the CPWC. The addition of $120 \mathrm{~kg} \mathrm{~N} \mathrm{ha}^{-1}$ delayed the beginning of the CPWC for all site-years when compared with the $0-\mathrm{kg} \mathrm{N} \mathrm{ha}^{-1}$ rate and for three of the four site-years when compared with the $60-\mathrm{kg} \mathrm{N} \mathrm{ha}^{-1}$ rate. The addition of $120 \mathrm{~kg} \mathrm{~N}$ $\mathrm{ha}^{-1}$ also hastened the end of the CPWC at three of the four site-years when compared with both reduced rates. The yield component most sensitive to both nitrogen and interference from weeds was seed number per ear. Practical implications of this study are that reductions in nitrogen use may create the need for more intensive weed management.
\end{abstract}

Nomenclature: Glyphosate; corn, Zea mays L. 'Dekalb DK589RR'.

Key words: Weed interference, competition, integrated weed management, critical time of removal, critical weed-free period.
One of the first steps in designing a successful integrated weed management (IWM) system is to identify the critical period for weed control (CPWC) in major crops (Swanton and Weise 1991). The CPWC is the period in the crop growth cycle during which weeds must be controlled to prevent unacceptable yield losses. The CPWC is determined by calculation of the time interval between two separately measured competition components: the critical duration of weed interference, the maximum length of time before earlyemerging weeds can grow and interfere with the crop before unacceptable yield loss is incurred, and the critical weed-free period, the minimum length of time required for the crop to be maintained weed free before yield loss caused by subsequent emerging weeds is no longer of concern (Weaver and Tan 1983). Consequently, interference from weeds before or after the CPWC will not result in unacceptable reductions in yield.

Knowledge of the CPWC and the factors that affect it is essential for making decisions on the appropriate timing of weed control and in achieving the efficient use of herbicides (Knezevic et al. 2002; Mulugeta and Boerboom 2000; Van Acker et al. 1993). Hall et al. (1992) reported that the beginning of the CPWC for corn varied from the 3- to 14leaf stages of the crop and ended consistently with the 14leaf stage, whereas Ferrero et al. (1996) calculated a CPWC beginning with the one- and seven-leaf stages and ending with the 7-and 10-leaf stages of the crop. Corn grain yield was reduced by $10 \%$ when wild proso millet (Panicum dihotomiflorum Michx.) removal was delayed for 2 wk after planting, and a 4- to 5-wk weed-free period was required after corn planting to avoid significant yield losses (Wilson and Westra 1991). A critical period for johnsongrass (Sorghum halepense L.) control in corn was reported to occur between 3 and 6.5 wk after crop emergence (Gosheh et al. 1996).

Previous research has suggested that the exact outcome of crop-weed interference is dependent on many site-specific factors, particularly the availability of essential nutrients (Di Tomaso 1995; Nieto and Staniforth 1961; Teyker et al. 1991; Tollenaar et al. 1994b; Vengris et al. 1955; Weaver et al. 1992). Therefore, nutrient management has been identified as a likely strategy for weed management (Walker and Buchanan 1982). Nitrogen is applied on $98 \%$ of field corn grown in the United States (Anonymous 2000a), but limited research has been conducted to determine the influence of nitrogen fertilization on corn-weed interference relationships, particularly for studies investigating the CPWC.

Furthermore, a number of factors are putting pressure on producers to reduce nitrogen applications in corn. The use of nitrogen in agricultural operations has been linked with high nitrate levels in ground and surface waters (Anonymous 2000b; Burkart and James 1999; Goss et al. 1995). In Nebraska, concerns of excessive nitrogen application have led to the development of regional attempts to reduce nitrogen use (Anonymous 1997). Because most nitrogen rate experiments are conducted in weed-free environments and most weed control experiments are conducted in the absence of nitrogen limitations, there is a need to evaluate the effects 
of nitrogen on the CPWC. Therefore, the objectives of this study were to (1) determine the CPWCs in dryland corn for differing levels of nitrogen fertilizer, and (2) identify the yield components most affected by nitrogen, the duration of weed interference, and the length of the weed-free period.

\section{Materials and Methods}

\section{Site Description}

Field experiments were conducted in 1999 and 2000 at the University of Nebraska Agricultural Research and Development Center (ARDC) near Mead, NE, and at the Haskell Agricultural Laboratory (HAL) near Concord, NE. Experiments were located in different fields in subsequent years. Soil types were a Sharpsburg silty clay loam, 0 to $2 \%$ slopes (fine, montmorillonitic, mesic Typic Argiudolls), with inclusions of the Butler series silty clay loam, 0 to $2 \%$ slopes (fine, montmorillonitic, mesic Abruptic Argiaquaolls), for both years at ARDC and the Kennebec series silty clay loam, 0 to $2 \%$ slopes (fine-silty, mixed, mesic Cumulic Hapludolls), for both years at HAL.

\section{Experimental Design and Procedures}

Each year, primary tillage consisted of fall chisel plowing at ARDC and spring disking at HAL. Before crop planting, a composite of five evenly distributed soil cores $(0.05-\mathrm{m}$ diameter) separated by depth increments of 0 to $0.15 \mathrm{~m}$, 0.15 to $0.60 \mathrm{~m}$, and 0.60 to $1.2 \mathrm{~m}$ was obtained from each replicate. Residual nitrate-nitrogen was determined from a depth of $1.2 \mathrm{~m}$. Soil organic matter, plant extractable phosphorous, and soluble potassium were determined from the surface layer $(0$ to $0.15 \mathrm{~m})$. As dictated by soil test levels, triple superphosphate fertilizer was broadcast at a rate equivalent to $45 \mathrm{~kg} \mathrm{P}_{2} \mathrm{O}_{5} \mathrm{ha}^{-1}$ at the ARDC location in 1999 and 2000, 2 wk before planting. For all sites, urea was broadcast before planting at rates equivalent to 0,60 , or $120 \mathrm{~kg} \mathrm{~N} \mathrm{ha}^{-1}$ using a ground-driven fertilizer drop spreader. ${ }^{1}$ The $120-\mathrm{kg} \mathrm{N} \mathrm{ha}{ }^{-1}$ rate was pertinent as an upper limit for nitrogen application in this study because this rate meets or slightly exceeds the recommended nitrogen rate for all locations calculated using soil organic matter content, residual nitrate level, and a weed-free grain yield goal of $8 \mathrm{Mg}$ $\mathrm{ha}^{-1}$ (Hergert et al. 1995). Immediately after nitrogen application, one or more secondary tillage operations were performed to incorporate the fertilizer and prepare a weed-free seedbed for planting.

A glyphosate-resistant corn hybrid Dekalb DK589RR 2 was planted at densities of 66,000 seeds ha ${ }^{-1}$ in 1999 and 58,000 seeds $\mathrm{ha}^{-1}$ in 2000 in $0.76-\mathrm{m}$ rows. Differences in seeding rates are due to differences in planting implements available to conduct these field trials. However, all seeding rates were within the recommended range for optimal yield of dryland corn in Nebraska. In 1999, corn was planted on May 25 and May 13 at the HAL and ARDC locations, respectively, and in 2000, planting took place on May 11 and May 2 at the HAL and ARDC locations, respectively. At the time of planting, a band of commercially formulated tefluthrin, (2,3,5,6-tetrafluoro-4-methylphenyl)methyl$(1 \alpha, 3 \alpha)-Z( \pm)$-3-(2-chloro-3,3,3-trifluoro-1-propenyl)-2,2dimethylcyclopropanecarboxylate, was applied within the cornrow at a rate of $0.2 \mathrm{~kg}$ ai ha ${ }^{-1}$ to control subterranean

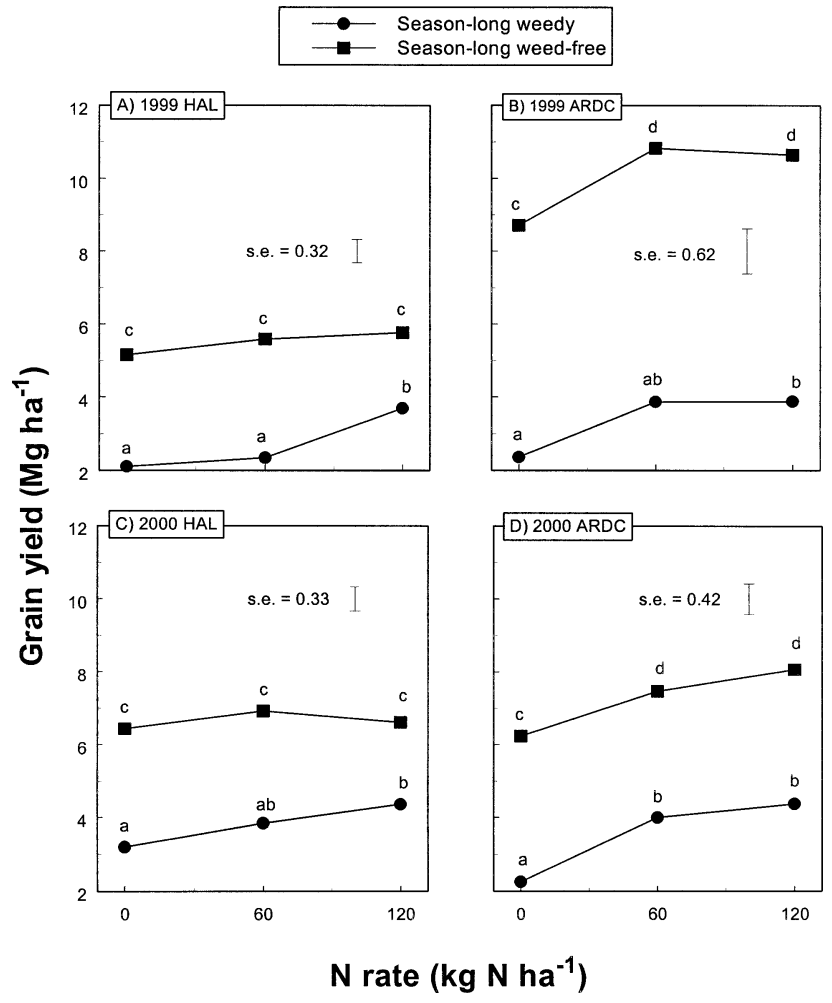

FIgure 1. Mean corn (Zea mays L.) yield response to three nitrogen rates at two sites in Nebraska in 1999 and 2000 in season-long weedy (O) and season-long weed-free $(\square)$ experimental units. Error bars represent \pm standard error (SE) of the treatment means. Yield comparisons are made within a site-year and are significantly different $(\mathrm{P}<0.05)$ when not designated with the same letter.

insect pests. Observable weed emergence was noted $2 \mathrm{~d}$ after crop emergence at HAL in 1999, $4 \mathrm{~d}$ before crop emergence at the ARDC in 1999, $4 \mathrm{~d}$ after crop emergence at HAL in 2000, and $5 \mathrm{~d}$ after crop emergence at the ARDC in 2000.

Experiments were established as a factorial arrangement of treatments in a split-plot randomized complete block design with nitrogen application level $(0,60$, or $120 \mathrm{~kg} \mathrm{~N}$ $\mathrm{ha}^{-1}$ ) as the main-plot factor and timing or duration of weed control as the split-plot factor. Split-plot experimental units consisted of six corn rows, $12.2 \mathrm{~m}$ in length. Main plots were arranged in randomized complete blocks with four replications at each location. For each main plot, two sets of treatments were imposed on the split-plot experimental units to represent both increasing duration of weed interference and the length of the weed-free period measured after planting. The first set of treatments established five levels of increasing duration of weed interference by delaying weed control from the time of crop planting up to predetermined crop growth stages (weedy up to V3, V6, V9, V15, and R1) at which weed control was initiated and maintained for the remainder of the growing season. The second set of treatments established five levels of increasing length of the weed-free period by maintaining weed control from the time of crop planting up to the above-presented crop growth stages before subsequently emerging weeds were left uncontrolled for the remainder of the season. In addition, seasonlong weedy and weed-free controls were included. Growth stages of the crop were determined from the number of visible leaf collars, as described by Ritchie et al. (1997). The progression of crop development was monitored for all 
TABLE 1. Parameter estimates with standard errors of the three-parameter logistic model used to determine the critical timing of weed removal for three levels of nitrogen application at two Nebraska sites in 1999 and 2000. The model was fit to relative yields of corn (Zea mays L.) (expressed as a percentage of the weed-free control) as a function of increasing duration of weed interference (in growing degree days). Refer to text (Equation 1) for model description. ${ }^{a}$

\begin{tabular}{|c|c|c|c|c|c|}
\hline \multirow{2}{*}{$\begin{array}{l}\text { Year and } \\
\text { location }\end{array}$} & \multirow[b]{2}{*}{$\mathrm{N}$ rate } & \multicolumn{4}{|c|}{ Parameter estimates } \\
\hline & & $K$ & $D$ & $F$ & RMSE \\
\hline \multicolumn{6}{|c|}{$\mathrm{kg} \mathrm{N} \mathrm{ha}{ }^{-1}$} \\
\hline \multirow[t]{3}{*}{1999 HAL } & 0 & $0.0065(0.0015)$ & $500(56)$ & $1.7078(0.1463)$ & 10.9 \\
\hline & 60 & $0.0039(0.0012)$ & $900(237)$ & $1.3215(0.3719)$ & 10.9 \\
\hline & 120 & $0.0066(0.0028)$ & $480(92)$ & $2.7834(0.4179)$ & 10.9 \\
\hline \multirow[t]{3}{*}{1999 ARDC } & 0 & $0.0094(0.0039)$ & $391(47)$ & $1.4873(0.1131)$ & 12.8 \\
\hline & 60 & $0.0065(0.0015)$ & $466(64)$ & $1.4315(0.1235)$ & 12.8 \\
\hline & 120 & $0.0064(0.0018)$ & $516(73)$ & $1.5524(0.1584)$ & 12.8 \\
\hline \multirow[t]{3}{*}{$2000 \mathrm{HAL}$} & 0 & $0.0071(0.0020)$ & $400(60)$ & $1.9094(0.1894)$ & 9.9 \\
\hline & 60 & $0.0052(0.0016)$ & $426(95)$ & $2.1951(0.3015)$ & 9.9 \\
\hline & 120 & $0.0066(0.0030)$ & $500(102)$ & $2.7667(0.4621)$ & 9.9 \\
\hline \multirow{3}{*}{2000 ARDC } & 0 & $0.0064(0.0015)$ & $350(50)$ & $1.5069(0.1084)$ & 10.8 \\
\hline & 60 & $0.0078(0.0025)$ & $530(74)$ & $2.0584(0.2299)$ & 10.8 \\
\hline & 120 & $0.0057(0.0019)$ & $540(97)$ & $2.1498(0.2991)$ & 10.8 \\
\hline
\end{tabular}

a Abbreviations: HAL, Haskell Agricultural Laboratory; ARDC, Agricultural Research and Development Center; RMSE, root mean square error.

weedy and weed-free controls by recording the average growth stage of 10 consecutive corn plants every $5 \mathrm{~d}$. As the season progressed, delays in crop development were noted in the presence of weed interference and where the applied nitrogen rate was $0 \mathrm{~kg} \mathrm{~N} \mathrm{ha}^{-1}$. Therefore, the timing of each weed removal was based on the average growth stage of the weedy plots from the $120-\mathrm{kg} \mathrm{N} \mathrm{ha}^{-1}$ rate. The growing degree days (GDD) accumulated by that time could then be related to the actual growth stage of the crop in the weedy controls of the other rates.

For initial weed removals before V15, weed control was achieved using glyphosate at $1.1 \mathrm{~kg}$ ai ha ${ }^{-1}$ with ammonium sulfate at $3.2 \mathrm{~kg} \mathrm{ha}^{-1}$. Applications were made with a bicycle wheel sprayer equipped with nine Teejet XR $110015^{3}$ nozzles spaced $50 \mathrm{~cm}$ apart and calibrated to deliver a volume of $187 \mathrm{~L} \mathrm{ha}^{-1}$ at a pressure of $207 \mathrm{kPa}$. Because of crop and weed size at V15 and R1, weed removal was conducted by hand for these removal times. Beginning $5 \mathrm{~d}$ after initial treatment, all subsequent emerging weeds were removed weekly by hand.

\section{Weed Harvests}

Two days before each weed removal, weeds were harvested from two $0.25-\mathrm{m}^{2}$ quadrats staggered on each side of the second corn row within each split-plot experimental unit. Successive harvest areas were separated from one another by a minimum of $1 \mathrm{~m}$ of undisturbed vegetation. Harvests were excluded from a $2-\mathrm{m}$ portion of both the front and rear of each split-plot experimental unit to minimize neighborhood effects. At each harvest, the height of the main weed canopy was measured. Weeds were clipped at the soil surface, sorted by species, counted, and dried at $70 \mathrm{C}$ to a constant moisture content.

\section{Corn Final Harvest}

Final harvest dates were October 12, 1999, and September 25, 2000, at the HAL site and October 5, 1999, and September 19, 2000, at the ARDC site. Corn ears were hand-harvested from $4 \mathrm{~m}$ of two adjacent rows within each split plot. Ears were threshed ${ }^{4}$ and subsequently dried at 70 C to a constant moisture content. All yields are presented and analyzed on a dry weight basis to eliminate the error associated with adjusting moisture content. Three days before the final grain harvest, plant number per area, ear number per plant, seed number per ear, and seed weight were determined from plants harvested from an additional $1 \mathrm{~m}$ of row ( 4 to 5 plants). Ears were dried at $70 \mathrm{C}$ to a constant moisture content and were shelled by hand. Approximately 500 to 700 seeds were counted with an automated seed counter $^{5}$ and weighed to determine 100 -seed weight. Seed number per ear was determined by dividing total grain weight of the sample by the number of ears harvested and dividing the product by mean seed weight.

\section{Data Analysis}

Actual yields and relative yields were subjected to an overall analysis of variance using PROC MIXED (Littell et al. 1996) in SAS. ${ }^{6}$ Relative yield of each experimental unit was calculated as a percentage of the corresponding weed-free yield for each nitrogen level. The significance of interactions between years, locations, and treatment combinations was evaluated at the $\mathrm{P}=0.05$ level.

\section{Critical Period Determination}

Mixed-model nonlinear regression analysis using PROC NLMIXED in SAS was used to model relative yield as a function of increasing duration of weed interference and length of the weed-free period, according to the procedure outlined by Knezevic et al. (2002).

A three-parameter logistic equation, modified slightly from the form proposed by Hall et al. (1992), was used to describe the effect of increasing duration of weed interference on relative yield and to determine the beginning of the CPWC (weedy curve) for each nitrogen rate:

$$
\begin{aligned}
R Y= & ((1 /(\exp (K(\mathrm{GDD}-D))+F)) \\
& +((F-1) / F)) 100
\end{aligned}
$$


TABle 2. Parameter estimates with standard errors of the Gompertz model used to determine the critical weed-free period for corn (Zea mays L.) for three levels of nitrogen application at two Nebraska sites in 1999 and 2000. The model was fit to relative yields of corn (expressed as a percentage of the weed-free control) as a function of increasing length of weed-free period (in growing degree days). Refer to text (Equation 2) for model description. ${ }^{a}$

\begin{tabular}{|c|c|c|c|c|c|}
\hline \multirow{2}{*}{$\begin{array}{l}\text { Year and } \\
\text { location }\end{array}$} & \multirow[b]{2}{*}{$\mathrm{N}$ rate } & \multicolumn{4}{|c|}{ Parameter estimates } \\
\hline & & $a$ & $b$ & $k$ & RMSE \\
\hline \multicolumn{6}{|c|}{$\mathrm{kg} \mathrm{N} \mathrm{ha}^{-1}$} \\
\hline \multirow{2}{*}{1999 HAL } & 60 & $105.12(4.18)$ & $0.9878(0.1537)$ & $0.0048(0.0010)$ & 10.9 \\
\hline & 120 & $102.99(5.77)$ & $0.5229(0.1206)$ & $0.0031(0.0011)$ & 10.9 \\
\hline 1999 ARDC & 0 & $104.74(4.04)$ & $1.2287(0.2243)$ & $0.0081(0.0022)$ & 12.6 \\
\hline \multirow[t]{3}{*}{$2000 \mathrm{HAL}$} & 0 & $99.28(5.29)$ & $0.6809(0.1092)$ & $0.0038(0.0013)$ & 9.9 \\
\hline & 60 & $100.30(4.28)$ & $0.5647(0.0993)$ & $0.0045(0.0015)$ & 9.9 \\
\hline & 120 & $103.00(3.85)$ & $0.4585(0.0895)$ & $0.0048(0.0017)$ & 9.9 \\
\hline \multirow[t]{3}{*}{2000 ARDC } & 0 & $104.12(5.96)$ & $1.4700(0.2253)$ & $0.0031(0.0006)$ & 10.8 \\
\hline & 60 & $105.30(5.02)$ & $0.8744(0.1308)$ & $0.0033(0.0007)$ & 10.8 \\
\hline & 120 & $106.12(5.18)$ & $0.8600(0.1255)$ & $0.0031(0.0006)$ & 10.8 \\
\hline
\end{tabular}

a Abbreviations: HAL, Haskell Agricultural Laboratory; ARDC, Agricultural Research and Development Center; RMSE, root mean square error.

where RY is relative yield (\% season-long weed-free yield), GDD is the duration of weed interference measured from the time of planting in growing degree days $(\mathrm{C} \mathrm{d}), \mathrm{D}$ is the point of inflection in GDD, and $\mathrm{K}$ and $\mathrm{F}$ are constants.

The Gompertz model (Hall et al. 1992) was used to describe the effect of increasing length of the weed-free period on relative yield and to determine the end of the CPWC (weed-free curve) for each nitrogen rate:

$$
\mathrm{RY}=a \times \exp (-b \times \exp [-k \times \mathrm{GDD}])
$$

where RY is relative yield (\% season-long weed-free yield), $a$ is the yield asymptote, $b$ and $k$ are constants, and GDD is the length of the weed-free period after crop planting in growing degree days.

Air GDD were used as the explanatory variable in the regression analysis and were accumulated from the date of planting. A base temperature $\left(T_{\mathrm{b}}\right)$ of $10 \mathrm{C}$ was used as the minimum temperature for corn growth, whereas $30 \mathrm{C}$ was used as the air temperature associated with optimal growth $\left(T_{\mathrm{o}}\right)$ (Gilmore and Rogers 1958). The time of crop planting was used as the reference point for accumulation of GDD to account for the possibility of weeds emerging before the crop. The GDD corresponding to the beginning and end of the CPWC were then related to crop growth stage so that the CPWC could be expressed in terms of crop phenological development.

Determination of the CPWC in these experiments was based on an acceptable yield loss level of 5\%. The GDD estimate corresponding to $95 \%$ relative yield was calculated for each equation using the calibration method developed by Schwenke and Milliken (1991) and modified for application to nonlinear mixed models. Differences in the critical timing of weed removal and the critical weed-free period between nitrogen rates were evaluated using pairwise $t$ tests at the $\mathrm{P}<0.05$ level (Schwenke and Milliken 1991).

Use of $5 \%$ as an acceptable yield loss level may or may not be that which would be used in practice but was used for this study to maintain consistency with similar works (Gosheh et al. 1996; Hall et al. 1992). Furthermore, although arbitrarily chosen, a 5\% level of yield loss is a likely compromise between what is acceptable to a producer and what is required for detection of statistical differences in yield. Given the variable nature of yield data, the use of an acceptable yield loss that would ensure statistical significance will not be accepted widely among agricultural practitioners. Furthermore, the use of an acceptable yield loss level that ensures statistical significance could have serious economic repercussions if used in practical weed control (Cousens 1988).

\section{Yield Component Analysis}

The effects of increasing the duration of weed interference and the length of the weed-free period on corn yield components were evaluated using linear or nonlinear regression. A linear $\left(y=p_{1}+p_{2} x\right)$ mixed regression model (Littell et al. 1996) was used to describe the effects of increasing duration of weed interference and length of the weed-free period $(x)$ on the yield components of plant density, ear number per plant, and seed weight. Significance of slopes $\left(p_{2}\right)$ were tested $(t$ test, $\mathrm{P}<0.05)$ against the null hypothesis that slopes were equal to zero for each nitrogen rate. If slopes were significant, then linear contrasts were constructed to test the equality of the slopes and intercepts $\left(p_{1}\right)$ between nitrogen rates. If the slopes were not significant, then comparisons were made between treatment means.

Nonlinear regression was used to describe the effect of treatments on seed number per ear using the technique used for fitting Equations 1 and 2 to relative yield data. However, the effect of increasing duration of weed interference on seed number per ear was best characterized by a four-parameter logistic equation (Ratkowsky 1990):

$$
\begin{array}{r}
S=S_{\text {min }}+\left(S_{\text {max }}-S_{\text {min }}\right) /[1+\exp (-W+Z \times \mathrm{GDD})][3] \\
\end{array}
$$

where $S$ is the number of seeds per ear, $S_{\min }$ is the lower asymptote, the predicted value of seed number per ear under season-long weed-free conditions, $S_{\max }$ is the upper asymptote, the predicted value of seed number per ear under season-long weedy conditions, GDD is the duration of weed 

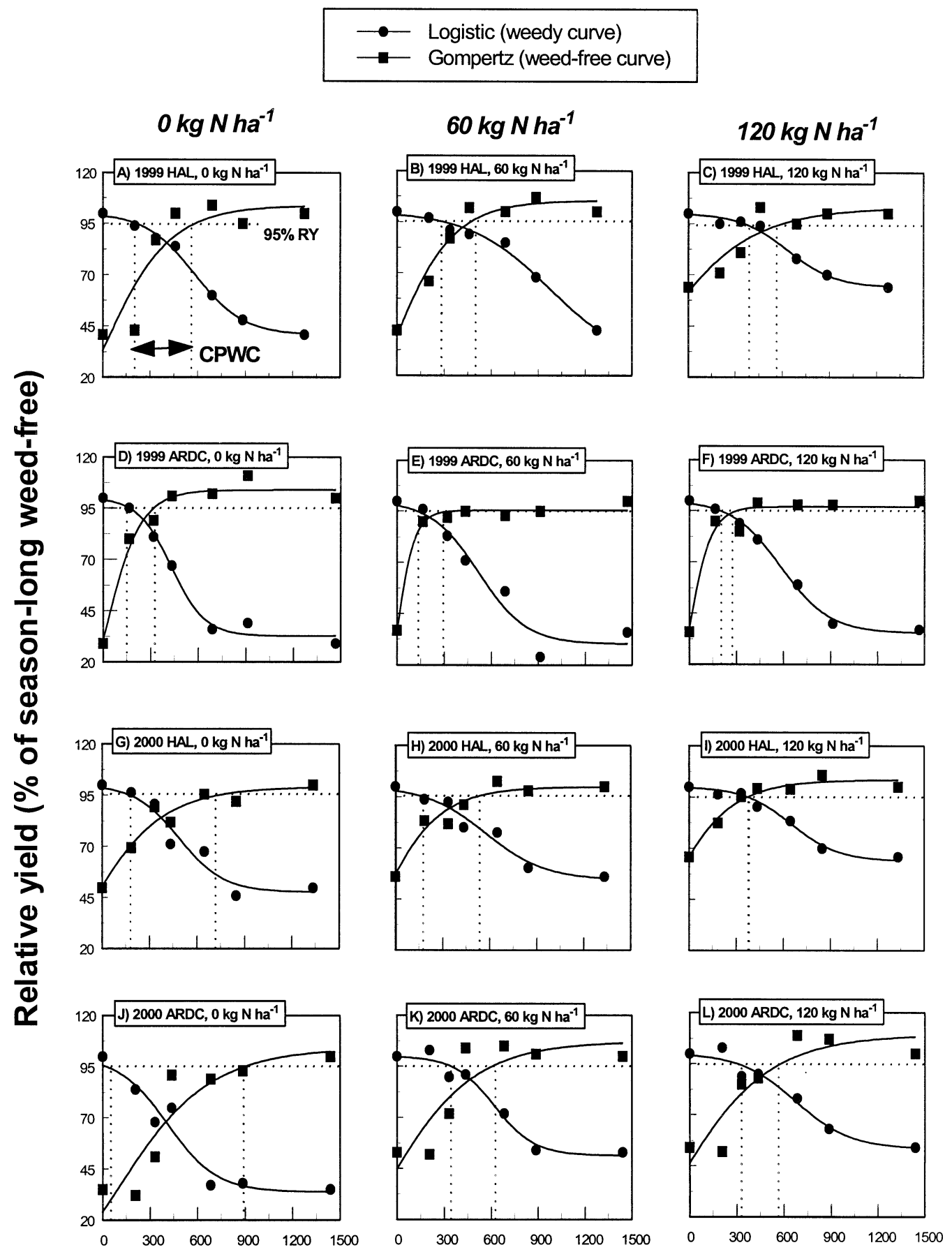

\section{Growing degree days - after planting (C d)}

FIGURE 2. Corn (Zea mays L.) relative yield (RY) expressed as a percentage of the weed-free control as a function of increasing duration of weed interference

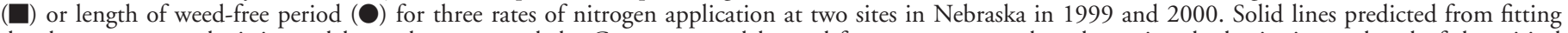
the three-parameter logistic model, weedy curve, and the Gompertz model, weed-free curve, are used to determine the beginning and end of the critical period for weed control (CPWC), respectively. Refer to Tables 1 and 2 for parameter estimates and Equations 1 and 2 in the text for model explanation. Horizontal dashed lines indicate the 5\% acceptable yield loss level used to determine both the beginning and end of the CPWC, whereas vertical dashed lines indicate the growing degree days, which produce a model solution of $95 \%$ RY.

interference in units of air growing degree days, and $W$ and $Z$ are constants. The four-parameter logistic model was selected because a solution to the three-parameter logistic model (Equation 1) presented above could not be derived for all site-years. As with relative yield data, the effect of length of the weed-free period on seed number per ear was best described with the Gompertz model (Equation 2) presented above, with the response variable and upper asymptotes reflecting seed number per ear rather than relative yield. 
TABLE 3. The critical period of weed controla (CPWC) for corn (Zea mays L.) at three levels of nitrogen application for two Nebraska sites in 1999 and 2000 expressed in growing degree days (GDD), corresponding crop growth stage ${ }^{\mathrm{b}}$ (CGS), and days after crop emergence (DAE).

\begin{tabular}{|c|c|c|c|c|c|c|c|}
\hline \multirow{2}{*}{$\begin{array}{l}\text { Year and } \\
\text { location }^{\mathrm{c}, \mathrm{d}}\end{array}$} & \multirow[b]{2}{*}{$\mathrm{N}$ rate } & \multicolumn{3}{|c|}{ Beginning of CPWC } & \multicolumn{3}{|c|}{ End of CPWC } \\
\hline & & GDD & CGS & DAE & GDD & CGS & DAE \\
\hline & $\mathrm{kg} \mathrm{N} \mathrm{ha}^{-1}$ & $\mathrm{C} \mathrm{d}$ & & $\mathrm{d}$ & $\mathrm{Cd}$ & & $\mathrm{d}$ \\
\hline \multirow[t]{3}{*}{$1999 \mathrm{HAL}$} & 0 & $212 \mathrm{a}$ & V3 & 14 & $581 \mathrm{a}$ & V11 & 47 \\
\hline & 60 & $285 \mathrm{~b}$ & V4 & 19 & $495 \mathrm{~b}$ & V10 & 41 \\
\hline & 120 & $360 \mathrm{c}$ & V7 & 28 & $590 \mathrm{a}$ & V12 & 48 \\
\hline \multirow[t]{3}{*}{1999 ARDC } & 0 & $145 \mathrm{a}$ & $\mathrm{V} 2$ & 8 & $312 \mathrm{a}$ & V6 & 23 \\
\hline & 60 & $130 \mathrm{a}$ & $\mathrm{V} 2$ & 7 & $300 \mathrm{a}$ & Late V5 & 22 \\
\hline & 120 & $200 \mathrm{~b}$ & V4 & 14 & $281 \mathrm{~b}$ & V5 & 21 \\
\hline \multirow{3}{*}{$2000 \mathrm{HAL}$} & 0 & $175 \mathrm{a}$ & V3 & 15 & $723 a$ & V18 & 63 \\
\hline & 60 & $177 \mathrm{a}$ & V3 & 16 & $525 \mathrm{~b}$ & V10 & 43 \\
\hline & 120 & $377 \mathrm{~b}$ & V7 & 31 & $365 c$ & V7 & 33 \\
\hline \multirow[t]{3}{*}{2000 ARDC } & 0 & $40 \mathrm{a}$ & $\mathrm{VE}$ & 1 & $897 \mathrm{a}$ & R1 & 72 \\
\hline & 60 & $345 \mathrm{~b}$ & V7 & 29 & $611 \mathrm{~b}$ & V13 & 52 \\
\hline & 120 & $330 \mathrm{~b}$ & V7 & 28 & $584 \mathrm{c}$ & V12 & 49 \\
\hline
\end{tabular}

a Based on a $5 \%$ acceptable yield loss level.

b Corn growth stages: VE, crop emergence; V2, two visible collars; V3, three visible collars; etc.; R1, corn anthesis.

${ }^{c}$ GDD within the same column and site-year that are followed by the same letter are not significantly different at the $\mathrm{P}=0.05$ level, according to pairwise $t$ tests.

d Abbreviations: HAL, Haskell Agricultural Laboratory; ARDC, Agricultural Research and Development Center.

\section{Results and Discussion}

\section{Corn Yield Response to Nitrogen}

Weed-free corn grain yields ranged from 5.2 to $11 \mathrm{Mg}$ $\mathrm{ha}^{-1}$ across years and locations of the experiment, whereas weedy corn yields ranged from 2.1 to $4.4 \mathrm{Mg} \mathrm{ha}^{-1}$. Location-related differences in weed-free yield are primarily attributed to rainfall amount and periodicity, with the greatest weed-free yields obtained at the ARDC in 1999, which received more timely rains during anthesis and grain-fill. The response of corn yield to nitrogen addition was inconsistent across locations and years. Weed-free yields for corn were independent of nitrogen addition in 1999 and 2000 at HAL (Figures 1A and 1C), most likely because of reduced yield potential due to drought. In contrast, the application of nitrogen positively influenced corn grain yields in the presence of weeds at HAL during both years compared with when no nitrogen was applied (Figures $1 \mathrm{~A}$ and $1 \mathrm{C}$ ). At ARDC, yield was positively influenced by nitrogen addition during both years (Figures $1 \mathrm{~B}$ and $1 \mathrm{D}$ ), but no significant differences in weed-free or weedy yields were observed between the 60 - and $120-\mathrm{kg} \mathrm{N} \mathrm{ha}^{-1}$ rates in 1999 or 2000.

\section{The Critical Period for Weed Control}

Because significant two-way interactions between locations within years and treatment levels were observed (data not shown), relative yield data were not pooled across years or locations. Instead, parameters for the logistic (Table 1) and Gompertz (Table 2) equations were obtained for each nitrogen application rate, and differences between the beginning and end of the CPWC were tested by site-year.

In all but one instance, the logistic (weedy) and Gompertz (weed free) curves used to identify the critical timing of weed removal and critical weed-free period overlapped in a manner that resulted in a CPWC where the critical timing of weed removal preceded the end of the critical weed-free period (Figure 2). The only instance where a CPWC defined in the classic sense (Nieto et al. 1968) could not be determined was for the $120-\mathrm{kg} \mathrm{N} \mathrm{ha}^{-1}$ rate at the $2000 \mathrm{HAL}$ site (Figure 2I), where both the critical timing of weed removal and the length of the critical weed-free period coincided with the V7 crop growth stage (Table 3), indicating that a single weed removal at this time was sufficient to prevent more than $5 \%$ yield loss.

\section{Critical Timing of Weed Removal}

Despite the inconsistent yield response to nitrogen (Figure 1), the beginning of the CPWC was delayed at the 120$\mathrm{kg} \mathrm{N} \mathrm{ha}{ }^{-1}$ rate when compared with the $0-\mathrm{kg} \mathrm{N} \mathrm{ha}^{-1}$ rate for all site-years. (Figure 2; Table 3). Without addition of nitrogen fertilizer, the beginning of the CPWC ranged from $40 \mathrm{GDD}$ at the ARDC in 2000 to $212 \mathrm{GDD}$ at HAL in 1999 , corresponding to the VE to V3 corn growth stages, respectively. At the $120-\mathrm{kg} \mathrm{N} \mathrm{ha}^{-1}$ rate, the beginning of the CPWC ranged from 200 GDD at the ARDC in 1999 to 377 GDD at HAL in 2000 , corresponding to the V4 to V7 corn growth stages, respectively (Figure 2; Table 3). The beginning of the CPWC was similar for the 0 - and $60-\mathrm{kg}$ $\mathrm{N} \mathrm{ha}^{-1}$ rates at the ARDC in 1999 and HAL in 2000. In contrast, the beginning of the CPWC at the ARDC in 2000 was different for the $0-\mathrm{kg} \mathrm{N} \mathrm{ha}^{-1}$ rate from those for both the 60 - and $120-\mathrm{kg} \mathrm{N} \mathrm{ha}^{-1}$ rates but was similar for the 60 - and $120-\mathrm{kg} \mathrm{N} \mathrm{ha}^{-1}$ rates (Table 3). These results indicate that an increase in nitrogen applied early in the growing season increased corn tolerance to the presence of weeds even when no yield response to nitrogen was observed. The mechanisms by which the addition of nitrogen reduces negative effects from weeds are not completely understood, but it is likely that nitrogen increased early-season corn growth rates, aiding in more timely corn leaf area expansion and improving the resiliency of corn leaf nitrogen content to the effects of weed interference (Evans 2001).

Differences in the beginning of the CPWC between years and locations can be attributed primarily to differences in 
TABLE 4. Mean weed dry weights with standard errors and species composition at two sites in Nebraska in 1999 and 2000 for three nitrogen rates measured in weedy experimental units at the V6 growth stage of corn (Zea mays L.).

\begin{tabular}{|c|c|c|c|c|c|c|c|}
\hline \multirow{2}{*}{$\begin{array}{l}\text { Year and } \\
\text { location }^{\mathrm{a}}\end{array}$} & \multirow[b]{2}{*}{$\mathrm{N}$ rate } & \multirow{2}{*}{$\begin{array}{c}\text { Weed } \\
\text { biomass }\end{array}$} & \multicolumn{5}{|c|}{ Species-specific contribution to weed biomass ${ }^{b}$} \\
\hline & & & ABUTH & AMASS & HELAN & POLPY & SETSS \\
\hline & $\mathrm{kg} \mathrm{N} \mathrm{ha-1}$ & $\mathrm{g} \mathrm{m}^{-2}$ & & . & - \% & 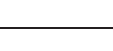 & \\
\hline \multirow[t]{3}{*}{1999 HAL } & 0 & $23(5)$ & 71 & 21 & 0 & 0 & 8 \\
\hline & 60 & $36(5)$ & 60 & 38 & 0 & 0 & 2 \\
\hline & 120 & $42(5)$ & 68 & 25 & 0 & 0 & 7 \\
\hline \multirow[t]{3}{*}{1999 ARDC } & 0 & $113(53)$ & 7 & 17 & 0 & 76 & 0 \\
\hline & 60 & $122(48)$ & 16 & 6 & 0 & 78 & 0 \\
\hline & 120 & $166(48)$ & 30 & 3 & 0 & 67 & 0 \\
\hline \multirow[t]{3}{*}{$2000 \mathrm{HAL}$} & 0 & $18(4)$ & 29 & 36 & 0 & 0 & 35 \\
\hline & 60 & $17(4)$ & 51 & 32 & 0 & 0 & 17 \\
\hline & 120 & $17(5)$ & 41 & 35 & 0 & 1 & 23 \\
\hline \multirow[t]{3}{*}{2000 ARDC } & 0 & $7(2)$ & 79 & 10 & 0 & 0 & 11 \\
\hline & 60 & $16(2)$ & 73 & 14 & 3 & 0 & 10 \\
\hline & 120 & $11(2)$ & 86 & 5 & 1 & 0 & 8 \\
\hline
\end{tabular}

a Abbreviations: HAL, Haskell Agricultural Laboratory; ARDC, Agricultural Research and Development Center.

b Weed species identified using WSSA-approved computer codes. ABUTH, velvetleaf, Abutilon theophrasti Medicus; AMASS, pigweed species, Amaranthus spp.; HELAN, common sunflower, Helianthus annuus L.; POLPY, Pennsylvania smartweed, Polygonum pensylvanicum L.; SETSS, foxtail species, Setaria spp.

the time of weed emergence relative to the crop and weed species. When averaged across nitrogen rates, the beginning of the CPWC occurred earlier for the ARDC in 1999 (i.e., before V3) than for any other site-year. Early-season weed biomass was greater (Table 4), and yield losses due to seasonlong weed interference were more substantial for the 1999 ARDC than for any other site-year, regardless of nitrogen rate (Figure 1). This was most likely due to the abundance of Pennsylvania smartweed (Polygonum pensylvanicum L.) that emerged $4 \mathrm{~d}$ before the crop. As a result, weeds were able to begin growth earlier than the crop, thus securing a competitive advantage. There was a delay in the beginning of the CPWC at the ARDC site in 2000 (Table 3). Despite an earlier beginning of the CPWC at the $0-\mathrm{kg} \mathrm{N}^{-1}$ rate at this location, the CPWC began, on average, at the V5 crop growth stage. Weed emergence at this location was delayed several days after emergence of the crop as indicated by the low densities and biomass measured at the V6 crop growth stage.

\section{Critical Weed-Free Period}

The end of the CPWC varied across locations and years ranging from $312 \mathrm{GDD}$ at the ARDC in 1999 to 897 GDD at the ARDC in 2000, or the V6 to R1 stages of corn growth for the $0-\mathrm{kg} \mathrm{N} \mathrm{ha}{ }^{-1}$ rate, and $281 \mathrm{GDD}$ at the ARDC in 1999 to 590 GDD at HAL in 1999, or the V5 to V12 stages of corn development for the $120-\mathrm{kg} \mathrm{N}$ $\mathrm{ha}^{-1}$ rate. In 1999 at HAL, the CPWC ended earlier for the $60-\mathrm{kg} \mathrm{N} \mathrm{ha}^{-1}$ rate than either the 0 - or $120-\mathrm{kg} \mathrm{N}^{-1}$ rate, whereas at the ARDC, the critical weed-free period was similar for the 0 - and $60-\mathrm{kg} \mathrm{N} \mathrm{ha}^{-1}$ rates but shorter for the 120-kg $\mathrm{N} \mathrm{ha}^{-1}$ rate (Figure 2; Table 3). In 2000, the

TABLE 5. Mean weed dry weights with standard errors and species composition at ARDC and HAL in 1999 and 2000 for three nitrogen application rates measured at corn (Zea mays L.) maturity in experimental units maintained weed free until the V9 growth stage of corn. ${ }^{a}$

\begin{tabular}{|c|c|c|c|c|c|}
\hline \multirow{2}{*}{$\begin{array}{l}\text { Year and } \\
\text { location }\end{array}$} & \multirow[b]{2}{*}{$\mathrm{N}$ rate } & \multirow{2}{*}{$\begin{array}{c}\text { Weed } \\
\text { biomass }\end{array}$} & \multicolumn{3}{|c|}{ Species-specific contribution to weed biomass ${ }^{b}$} \\
\hline & & & ABUTH & AMASS & SETSS \\
\hline & $\mathrm{kg} \mathrm{N} \mathrm{ha}{ }^{-1}$ & $\mathrm{~g} \mathrm{~m}^{-2}$ & 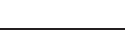 & - \% & \\
\hline \multirow[t]{3}{*}{1999 HAL } & 0 & $39(27)$ & 20 & 20 & 60 \\
\hline & 60 & $15(27)$ & 40 & 10 & 50 \\
\hline & 120 & $18(27)$ & 20 & 25 & 55 \\
\hline \multirow[t]{3}{*}{1999 ARDC } & 0 & $10(7)$ & 60 & 35 & 5 \\
\hline & 60 & $9(7)$ & 75 & 20 & 5 \\
\hline & 120 & $9(7)$ & 60 & 30 & 10 \\
\hline \multirow[t]{3}{*}{$2000 \mathrm{HAL}$} & 0 & $15(8)$ & 100 & 0 & 0 \\
\hline & 60 & $24(8)$ & 98 & 0 & 2 \\
\hline & 120 & $15(8)$ & 85 & 10 & 5 \\
\hline \multirow[t]{3}{*}{2000 ARDC } & 0 & $78(24)$ & 5 & 15 & 80 \\
\hline & 60 & 91 (19) & 15 & 10 & 75 \\
\hline & 120 & $168(24)$ & 10 & 20 & 70 \\
\hline
\end{tabular}

\footnotetext{
a Abbreviations: HAL, Haskell Agricultural Laboratory; ARDC, Agricultural Research and Development Center.

b Weed species identified using WSSA-approved computer codes. ABUTH, velvetleaf, Abutilon theophrasti Medicus; AMASS, pigweed species, Amaranthus spp.; SETSS, foxtail species, Setaria spp.
} 
end of the CPWC was hastened at both locations as nitrogen rates increased.

With the exception of the 1999 HAL site, an increase in nitrogen application decreased the length of the critical weed-free period because of a rapid canopy closure resulting from higher crop leaf area index (LAI) (data not shown). Increased LAI of the crop reduces both the quality and quantity of light reaching weeds in the lower layers of the canopy, hindering the establishment and growth of subsequent weed cohorts (Teasdale 1995). This is supported by the fact that increasing nitrogen rate did not consistently increase the biomass of weeds emerging after the V9 growth stage of corn (Table 5). Biomass of late-emerging weeds was responsive to nitrogen application only at the ARDC in $2000\left(\mathrm{P}=0.02, r^{2}=0.78, n=12\right)$.

Variability in the end of the CPWC across years and locations was mostly due to the periodicity of weed emergence. Maintenance of a weed-free period lasting only a few weeks at the ARDC 1999 site was sufficient to protect crop yields because the periodicity of weed emergence was limited to a relatively short length of time early in the season. In comparison with other site-years, weed densities and total aboveground weed biomass measured at corn maturity were much lower for the ARDC site in 1999 for experimental units kept weed free up to the V9 crop growth stage (Table 5). Similarly, Van Acker et al. (1993) reported that increase in the weed-free period caused a sharp decline in weed biomass and density because the weed-free period was extended beyond the time when the majority of the studied weeds typically emerge. In this study, the very short duration of the critical weed-free period at ARDC in 1999 was due to the fact that most weed emergence occurred at the earliest stages of crop growth, reducing competition late in the season.

The end of the CPWC may also be regulated by other factors affecting crop LAI, including the density of the crop. Crop densities were 60,000 to 64,000 plants $\mathrm{ha}^{-1}$ for both locations in 1999, but because of lower seeding rates and poorer crop establishment due to soil crusting in 2000, plant populations were as low as 50,000 plants $\mathrm{ha}^{-1}$. Within this range of corn population levels, LAI is positively correlated with an increase in plant density (Tetio-Kagho and Gardner 1988). Therefore, lower plant population in this study resulted in lower crop LAI, potentially reducing crop-induced inhibition of weed emergence and growth (Tollenaar et al. 1994a). Indeed, maximum LAI was greater for both locations in 1999 (LAI = 4.2) than in $2000(\mathrm{LAI}=3.3)$, which may have been a contributing factor that caused a somewhat later end to the CPWC for both sites in 2000.

\section{Corn Yield Components}

Yield components that are most sensitive to weed and nitrogen treatments should demonstrate primary control over observed differences in crop yield. Plant density was not affected significantly by the treatments. Ear number per plant declined linearly with increasing duration of weed interference but usually accounted for less than $10 \%$ of the total yield decline, with the greatest effects observed at the lowest nitrogen rate (data not shown). Similarly, 100-seed weight was negatively correlated with the duration of weed interference and positively correlated with the length of the weed-free period, but the effect was not always significant,

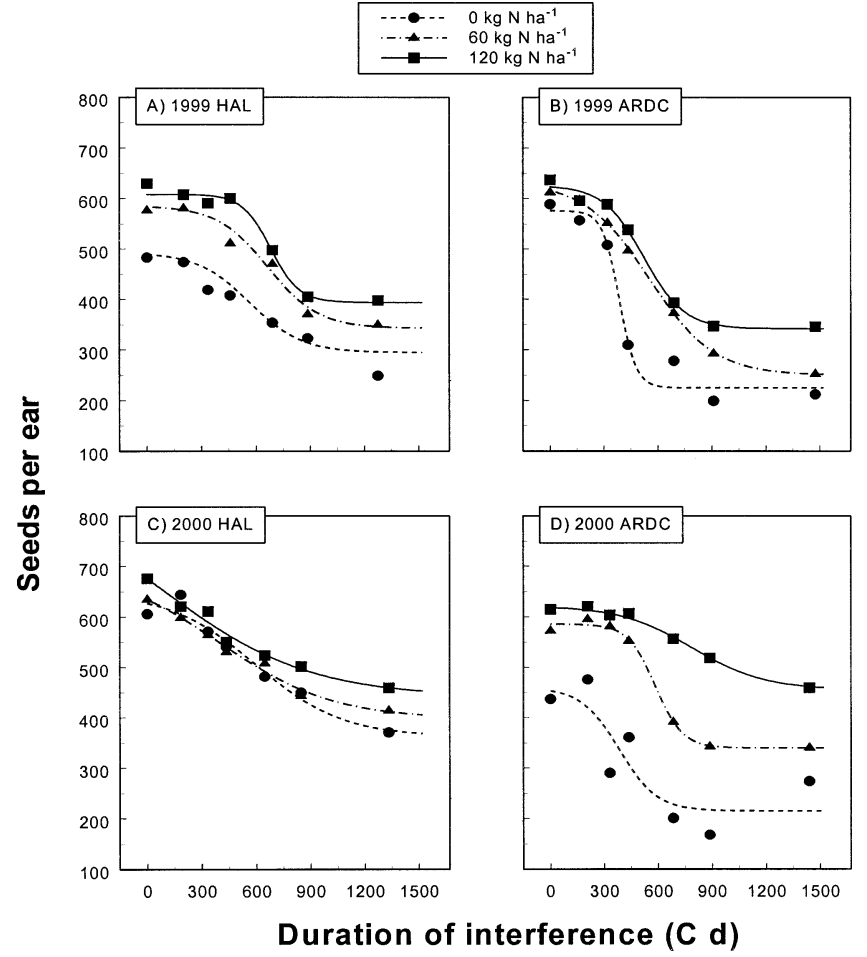

Figure 3. Corn (Zea mays L.) seed number per ear $(S)$ as a function of increasing duration of weed interference in growing degree days (GDD) at two sites in Nebraska in 1999 and 2000 for three rates of nitrogen application, $0(\mathbf{O}), 60(\mathbf{\Lambda})$, and $120(\square) \mathrm{kg} \mathrm{N} \mathrm{ha}^{-1}$, at two sites in Nebraska in 1999 and 2000. Lines are predicted from the fitted four-parameter logistic model. Refer to Equation 3 in the text for description of the model fitted. Fitted equations for 1999 HAL are: $S=295+198 /(1+\exp$ $[-3.94+0.0070 \times \mathrm{GDD}])$ at $0 \mathrm{~kg} \mathrm{~N} \mathrm{ha}^{-1}, S=343+243 /(1+\exp$ $[-4.75+0.0071 \times \mathrm{GDD}])$ at $60 \mathrm{~kg} \mathrm{~N} \mathrm{ha}^{-1}$, and $S=394+215 /(1+$ $\exp [-8.68+0.0127 \times \mathrm{GDD}])$ at $120 \mathrm{~kg} \mathrm{~N} \mathrm{ha}^{-1}$, root mean square error $($ RMSE) $=51.1$. Fitted equations for 1999 ARDC are: $S=225+348 /$ $(1+\exp [-8.28+0.0215 \times \mathrm{GDD}])$ at $0 \mathrm{~kg} \mathrm{~N} \mathrm{ha}^{-1}, S=250+383 /$ $(1+\exp [-3.07+0.0056 \times \mathrm{GDD}])$ at $60 \mathrm{~kg} \mathrm{~N} \mathrm{ha}^{-1}$, and $S=342+$ $284 /(1+\exp [-4.66+0.0089 \times$ GDD $])$ at $120 \mathrm{~kg} \mathrm{~N} \mathrm{ha}^{-1}$, RMSE $=$ 87.7. Fitted equations for $2000 \mathrm{HAL}$ are: $S=363+286 /(1+\exp [-2.40$ $+0.0042 \times \mathrm{GDD}])$ at $0 \mathrm{~kg} \mathrm{~N} \mathrm{ha}^{-1}, S=398+262 /(1+\exp [-1.28+$ $0.0032 \times \mathrm{GDD}])$ at $60 \mathrm{~kg} \mathrm{~N} \mathrm{ha}^{-1}$, and $S=442+258 /(1+\exp [-0.23$ $+0.0025 \times \mathrm{GDD}])$ at $120 \mathrm{~kg} \mathrm{~N} \mathrm{ha}^{-1}$, RMSE $=54.1$. Fitted equations for 2000 ARDC are: $S=215+245 /(1+\exp [-3.62+0.0095 \times \mathrm{GDD}])$ at $0 \mathrm{~kg} \mathrm{~N} \mathrm{ha}{ }^{-1}, S=340+246 /(1+\exp [-7.71+0.0132 \times$ GDD $])$ at $60 \mathrm{~kg} \mathrm{~N} \mathrm{ha}^{-1}$, and $S=456+166 /(1+\exp [-3.92+0.0050 \times \mathrm{GDD}])$ at $120 \mathrm{~kg} \mathrm{~N} \mathrm{ha}^{-1}$, RMSE $=79.6$.

accounting for only a minor portion of the observed yield loss (data not shown). Seed weight has been shown to be less variable than seed number except under conditions where the plant is highly stressed (Novoa and Loomis 1981).

In this study, the yield component most sensitive to weed interference and nitrogen was seed number per ear, which responded in a manner that closely resembled the pattern and extent of response in relative yield to both increasing duration of weed interference and length of the weed-free period. Increasing the duration of weed interference resulted in a sigmoidal decline in seed number per ear (Figure 3), emulating the decline in crop yield (Figure 2). In most cases, the effect was more immediate at the lowest nitrogen rate, which is consistent with determinations of the beginning of the CPWC. Similarly, the increase in seed number due to increases in the length of the weed-free period (Figure 4) matched the trend observed for the response of crop yield to length of the weed-free period. For a given duration of 


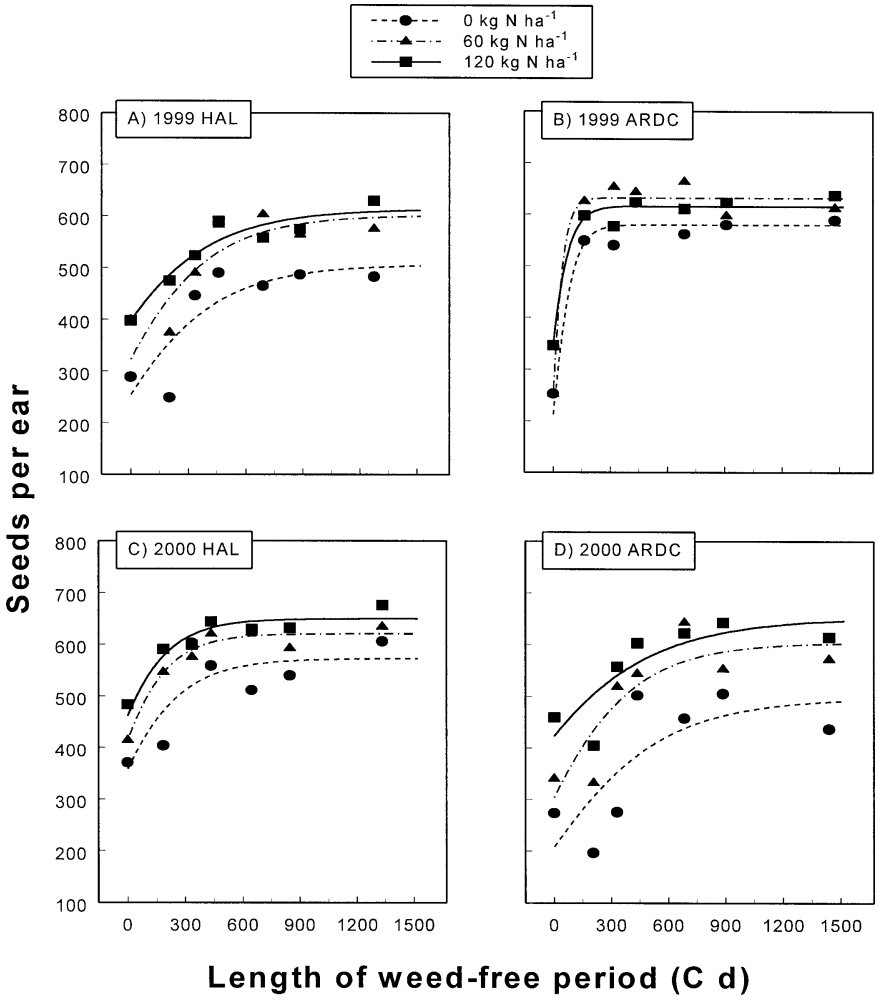

Figure 4. Corn (Zea mays L.) seed number per ear $(S)$ as a function of increasing length of weed-free period in growing degree days (GDD) at two sites in Nebraska in 1999 and 2000 for three rates of nitrogen application, $0(\mathbf{O}), 60(\mathbf{\Delta})$, and $120(\boldsymbol{\square}) \mathrm{kg} \mathrm{N} \mathrm{ha}^{-1}$, at two sites in Nebraska in 1999 and 2000. Lines are predicted from the fitted Gompertz model. Refer to Equation 2 in the text for description of the model fitted. Fitted equations for $1999 \mathrm{HAL}$ are: $S=506 \times \exp (-0.6871 \times \exp [-0.0033 \times$ GDD]) at $0 \mathrm{~kg} \mathrm{~N} \mathrm{ha}{ }^{-1}, S=602 \times \exp (-0.6220 \times \exp [-0.0035 \times$ GDD]) at $60 \mathrm{~kg} \mathrm{~N} \mathrm{ha}^{-1}$, and $S=614 \times \exp (-0.4365 \times \exp [-0.0031$ $\times$ GDD]) at $120 \mathrm{~kg} \mathrm{~N} \mathrm{ha}^{-1}$, root mean square error $(\mathrm{RMSE})=72.6$. Fitted equations for 1999 ARDC are: $S=580 \times \exp (-1.0056 \times$ $\exp [-0.0167 \times \mathrm{GDD}])$ at $0 \mathrm{~kg} \mathrm{~N} \mathrm{ha}^{-1}, S=632 \times \exp (-0.9172 \times$ $\exp [-0.0275 \times \mathrm{GDD}])$ at $60 \mathrm{~kg} \mathrm{~N} \mathrm{ha}^{-1}$, and $S=616 \times \exp (-0.5762$ $\times \exp [-0.0164 \times \mathrm{GDD}])$ at $120 \mathrm{~kg} \mathrm{~N} \mathrm{ha}^{-1}, \mathrm{RMSE}=52.6$. Fitted equations for $2000 \mathrm{HAL}$ are: $S=573 \times \exp (-0.4706 \times \exp [-0.0048 \times$ GDD] $)$ at $0 \mathrm{~kg} \mathrm{~N} \mathrm{ha}{ }^{-1}, S=621 \times \exp (-0.4031 \times \exp [-0.0061 \times$ GDD]) at $60 \mathrm{~kg} \mathrm{~N} \mathrm{ha}^{-1}$, and $S=650 \times \exp (-0.3421 \times \exp [-0.0057$ $\times$ GDD] $)$ at $120 \mathrm{~kg} \mathrm{~N} \mathrm{ha}^{-1}$, RMSE $=64.8$. Fitted equations for 2000 ARDC are: $S=498 \times \exp (-0.8714 \times \exp [-0.0028 \times \mathrm{GDD}])$ at $0 \mathrm{~kg}$ $\mathrm{N} \mathrm{ha}^{-1}, S=605 \times \exp (-0.6868 \times \exp [-0.0035 \times \mathrm{GDD}])$ at $60 \mathrm{~kg} \mathrm{~N}$ $\mathrm{ha}^{-1}$, and $S=653 \times \exp (-0.4350 \times \exp [-0.0025 \times \mathrm{GDD}])$ at $120 \mathrm{~kg}$ $\mathrm{N} \mathrm{ha}{ }^{-1}$, RMSE $=79.4$.

weed interference or length of the weed-free period, the addition of nitrogen increased seed number per ear (Figures 3 and 4). Other authors also have suggested that seed number is the most significant contributor to observable differences in the grain yield of cereal crops. For example, Knezevic et al. (1997) reported that a reduction in seed number per head was the major cause of yield loss in grain sorghum [Sorghum bicolor (L.) Moench] because of competition with pigweed (Amaranthus retroflexus L.). El-Hattab et al. (1980) also showed that increase in seed number was a consistent factor in the yield increase of corn receiving sufficient doses of nitrogen fertilizer, whereas increases in ear number per plant and seed weight were secondary.

\section{Implications for IWM}

This study confirms that the supply of nitrogen available to a crop and weeds can significantly influence crop-weed interference relationships. Differences in the CPWC due to nitrogen application documented in this study highlight the importance of integrating decisions regarding nitrogen management and the timing of weed control.

Practical implications of this study are that reductions in nitrogen use may warrant more intensive weed management. With the growing popularity of herbicide-tolerant crops, dependence on total postemergence programs will likely become more common. Such a shift in cropping practices highlights the importance of appropriately timed weed control. This study shows that a $50 \%$ reduction in nitrogen applied before crop establishment (120 to $60 \mathrm{~kg} \mathrm{~N} \mathrm{ha}^{-1}$ ) may not result in less crop yield under weed-free conditions, but it is more likely that weed interference will have a more immediate and pronounced effect on yield potential. Therefore, reductions in the use of nitrogen fertilizer before crop planting may create the need for more immediate weed control that must be sustained for longer times.

\section{Sources of Materials}

${ }^{1}$ Barber Engineering Ltd., 1404 North Regal Street, Spokane, WA 99202.

2 Monsanto Inc., 800 North Lindbergh Boulevard, St. Louis, MO 63167.

3 Spraying Systems Co., P.O. Box 7900, Wheaton, IL 60189.

${ }^{4}$ John Deere model 43, Deere and Co., One John Deere Place, Moline, IL 61265.

5 Davis Tool and Engineering Co., Highway 30, Montgomery, IL 60538

${ }^{6}$ SAS Version 8.0, Statistical Analysis Systems Institute, 100 SAS Campus Drive, Cary, NC 27512.

\section{Acknowledgments}

Many thanks to Mary Guerra, Will Corcoran, Ray Brentlinger, Lisa Lunz, Mike Mainz, Christie McCoy, and Nathan Haahr for assisting with fieldwork. We also thank W. W. Stroup for assistance in the statistical analysis and many anonymous reviewers for their valuable comments. Published as University of Nebraska Agricultural Research Division Journal Series No. 13888.

\section{Literature Cited}

Anonymous. 1997. Upper Elkhorn Natural Resources District Ground Water Management Plan. Lincoln, NE: Nebraska Upper Elkhorn Natural Resources District. 155 p.

Anonymous. 2000a. Agricultural Chemical Usage: 1999 Field Crops Summary. Washington, DC: National Agricultural Statistics Service, U.S. Department of Agriculture. $112 \mathrm{p}$.

Anonymous. 2000b. National Water Quality Inventory: 1998 Report to Congress. Washington, DC: Office of Water, U.S. Environmental Protection Agency. 89 p.

Burkart, M. R. and D. E. James. 1999. Agricultural-N contributions to hypoxia in the Gulf of Mexico. J. Environ. Qual. 28:850-859.

Cousens, R. 1988. Misinterpretation of results in weed research through inappropriate use of statistics. Weed Res. 28:281-289.

DiTomaso, J. 1995. Approaches for improving crop competitiveness through the manipulation of fertilization strategies. Weed Sci. 43:491497.

El-Hattab, H. S., M. A. Abdallah Hussein, A. H. El-Hattab, M. S. Abdel Raouf, and A. A. El-Nomany. 1980. Growth analysis of maize plant in relation to grain yield as affected by $\mathrm{N}$ levels. Z. Acker- Pflanzenb. 149:46-57.

Evans, S. P. 2001. Effects of Varying Nitrogen Supply on the Critical Period for Weed Control in Corn (Zea mays L.). M.S. thesis. University of Nebraska, Lincoln, NE. 210 p.

Ferrero, A., M. Scanzio, and M. Acutis. 1996. Critical period of weed interference in maize. Pages 171-176 in Proceedings of the 2nd In- 
ternational Weed Control Congress. Copenhagen, Denmark: Danish Institute of Plant and Soil Science.

Gilmore, E. C. and R. S. Rogers. 1958. Heat units as a method of measuring maturity in corn. Agron. J. 50:611-615.

Gosheh, H. Z., D. L. Holshouser, and J. M. Chandler. 1996. The critical period of johnsongrass (Sorghum halepense) control in field corn (Zea mays). Weed Sci. 44:944-947.

Goss, M. J., E. G. Beauchamp, and M. H. Miller. 1995. Can a farming systems approach help minimize $\mathrm{N}$ losses to the environment? J. Contam. Hydrol. 20:285-297.

Hall, M. R., C. J. Swanton, and G. W. Anderson. 1992. The critical period of weed control in grain corn (Zea mays). Weed Sci. 40:441-447.

Hergert, G. W., R. B. Ferguson, and C. A. Shapiro. 1995. Fertilizer suggestions for corn. Lincoln, NE: University of Nebraska Institute of Agriculture and Natural Resources Cooperative Extension Publication No. G74-174-A.

Knezevic, S. Z., S. P. Evans, E. E. Blankenship, R. C. Van Acker, and J. L. Lindquist. 2002. Critical period for weed control: the concept and data analysis. Weed Sci. 50:773-786.

Knezevic, S. Z., M. J. Horak, and R. L. Vanderlip. 1997. Relative time of redroot pigweed (Amaranthus retroflexus L.) emergence is critical in pigweed-sorghum [Sorghum bicolor (L.) Moench] competition. Weed Sci. 45:502-508.

Littell, R. C., G. A. Milliken, W. W. Stroup, and R. D. Wolfinger. 1996. SAS System for Mixed Models. Cary, NC: Statistical Analysis Systems Institute. $633 \mathrm{p}$.

Mulugeta, D. and C. M. Boerboom. 2000. Critical time of weed removal in glyphosate-resistant Glycine max. Weed Sci. 48:35-42.

Nieto, H. J., M. A. Brondo, and J. T. Gonzales. 1968. Critical periods of the crop growth cycle for competition from weeds. Pest Art. News Summ. (C) 14:159-166.

Nieto, J. and D. W. Staniforth. 1961. Corn-foxtail competition under various production conditions. Agron. J. 53:1-5.

Novoa, R. and R. S. Loomis. 1981. N and plant production. Plant Soil 58:177-204

Ratkowsky, D. D. 1990. Handbook of Nonlinear Regression Models. New York: Marcel Dekker. pp. 128-138.

Ritchie, W. S., J. J. Hanway, and G. O. Benson. 1997. How a Corn Plant
Develops. Special Report No. 48 (Revised). Ames, IA: Iowa State University of Sciences and Technology, Cooperative Extension Service.

Schwenke, J. R. and G. A. Milliken. 1991. On the calibration problem extended to nonlinear models. Biometrics 47:563-574.

Swanton, C. J. and S. F. Weise. 1991. Integrated weed management: the rationale and approach. Weed Technol. 5:648-656.

Teasdale, J. R. 1995. Influence of narrow row/high population corn (Zea mays) on weed control and light transmittance. Weed Technol. 9:113118.

Tetio-Kagho, F. and F. P. Gardner. 1988. Responses of maize to plant population density. I. Canopy development, light relationships, and vegetative growth. Agron. J. 80:930-935.

Teyker, R. H., H. D. Hoelzer, and R. A. Liebl. 1991. Maize and pigweed response to N supply and form. Plant Soil 135:287-292.

Tollenaar, M., A. A. Dibo, A. Aguilera, S. F. Weise, and C. J. Swanton. 1994a. Effect of crop density on weed interference in maize. Agron. J. 86:591-595.

Tollenaar, M., S. P. Nissanka, A. Aguilera, S. F. Weise, and C. J. Swanton. 1994b. Effect of weed interference and soil $\mathrm{N}$ on four maize hybrids. Agron. J. 86:596-601.

Van Acker, R. C., C. J. Swanton, and S. F. Weise. 1993. The critical period of weed control in soybean [Glycine $\max$ (L.) Mer.]. Weed Sci. 41: 194-200.

Vengris, J., W. G. Colby, and M. Drake. 1955. Plant nutrient competition between weeds and corn. Agron. J. 47:213-216.

Walker, R. H. and G. A. Buchanan. 1982. Crop manipulation in integrated weed management systems. Weed Sci. 30(Suppl. 1):17-24.

Weaver, S. E., M. J. Kropff, and R. W. Groenevled. 1992. Use of ecophysiological models for crop-weed interference: the critical period of weed interference. Weed Sci. 40:302-307.

Weaver, S. E. and C. T. Tan. 1983. Critical period of weed interference in transplanted tomatoes (Lycopersicon esculentum): growth analysis. Weed Sci. 31:476-481.

Wilson, R. G. and P. Westra. 1991. Wild proso millet (Panicum miliaceum) interference in corn (Zea mays). Weed Sci. 39:217-220.

Received November 26, 2001, and approved October 24, 2002. 